\title{
Hybrid abalone are more robust to multi-stressor environments than pure parental species
}

\author{
Katharina Alter ${ }^{\mathrm{a}, \mathrm{b}}$, *, Sarah J. Andrewartha ${ }^{\mathrm{a}, \mathrm{b}}$, Andrea
Rafael I. León ${ }^{\mathrm{e}}$, Nicholas G. Elliott \\ b Agriculture and Food, Commonwealth Scientific and Industrial Research Organisation, Hobart, TAS, Australia \\ ${ }^{c}$ Department of Biology, Mount Allison University, Sackville, NB, Canada \\ d Data 61, Commonwealth Scientific and Industrial Research Organisation, Hobart, TAS, Australia \\ ${ }^{\mathrm{e}}$ Institute for Marine and Antarctic Studies, University of Tasmania, Taroona, TAS, Australia
}

\section{ART ICLE INFO}

\section{Keywords:}

Hybrid vigor

Abalone

Heart rate

Oxygen consumption rate

Movement

\begin{abstract}
Many hybrids of marine molluscs show improved growth in comparison to their pure parental species. Yet, little is known about the physiological mechanisms underlying the better hybrid performance. In this study, movement, oxygen consumption rate $\left(\dot{\mathrm{M}}_{\mathrm{O}_{2}}\right)$ and heart rate were determined in 22 month old cultured abalone Haliotis rubra, $H$. laevigata and their interspecies hybrid, the latter of which exhibits improved growth rate. Abalone were exposed to an acute temperature increase following acclimation to 16 or $23{ }^{\circ} \mathrm{C}$ at high and low oxygen levels ( $100 \%$ or $70 \%$ air saturation, respectively). Movement of hybrids and $H$. laevigata was generally not affected by temperature and oxygen levels, yet $H$. rubra showed a strong thermal response. Heart rate and $\dot{\mathrm{M}}_{\mathrm{O}_{2}} /$ temperature slopes revealed that hybrids were least affected by oxygen levels. Arrhenius break-point temperatures of hybrids and $H$. laevigata, but not $H$. rubra, were generally higher when abalone were acclimated to $23{ }^{\circ} \mathrm{C}$ in comparison to $16{ }^{\circ} \mathrm{C}$. Hybrids had more stable maximum heart rate and $\dot{\mathrm{M}}_{\mathrm{O}_{2}}$ values across acclimation conditions in comparison to $H$. laevigata and $H$. rubra. Thus, it appears that hybrids are able to maintain physiological functions over a broader environmental range. This improved tolerance to environmental fluctuations may bolster energy metabolism and improve growth in variable environments such as aquaculture farms.
\end{abstract}

\section{Introduction}

Heterosis or hybrid vigor occurs when an interspecies individual shows improved fitness or superior phenotypic traits in comparison to both parental pure species. A positive heterosis for growth has been reported for many shellfish species, including oysters, scallops, and abalone (Guo, 2009; Collins, 2013). The physiological mechanisms underlying superior performance of hybrids, however, are not well understood. It has been suggested that positive heterosis for growth rate may be caused by differences in metabolic efficiency, which can be measured through whole-animal metabolism (Toro et al., 1996).

The metabolic rate and ultimately the growth rate of marine ectotherms are strongly influenced by the environmental conditions to which individuals are exposed. Temperature and oxygen are the major driving factors. Oxygen is required in the aerobic pathways that produce the energy needed to drive all cellular reactions (Dahlhoff and
Somero, 1993; Grieshaber et al., 1993). During exposure to hypoxia, species that are adapted to this condition, undergo metabolic suppression which results in reduced oxygen consumption rates $\left(\dot{\mathrm{M}}_{\mathrm{O}_{2}}\right)$ (Storey and Storey, 1990). In contrast, species that are not adapted to hypoxia modify physiological functions to increase oxygen uptake, for example by increasing their heart stroke volume amongst others (Ragg and Taylor, 2006). The rate of oxygen consumption increases with temperature throughout the ecological range resulting in increased heart rate to transport the required oxygen to the cells where it is needed. As a result, $\dot{\mathrm{M}}_{\mathrm{O}_{2}}$ and heart rate typically correlate across ecologically relevant temperatures. This correlation is finite and $\dot{\mathrm{M}}_{\mathrm{O}_{2}}$ and heart rate will reach a maximum at a critical temperature above which animals can no longer function (Dahlhoff and Somero, 1993). This upper critical temperature can be calculated as the log of physiological rate against temperature (Arrhenius plots) and is also known as the Arrhenius break-point temperature (Dahlhoff and Somero, 1993). Thus, $\dot{\mathrm{M}}_{\mathrm{O}_{2}}$ and heart rates can give valuable insight into the metabolism and thermal

\footnotetext{
* Corresponding author at: Institute for Marine and Antarctic Studies, University of Tasmania, Castray Esplanade, Hobart 7001, TAS, Australia.

Email address: katharina.alter@gmail.com (K. Alter)
} 
sensitivity of an animal (Dahlhoff and Somero, 1993; Marshall and McQuaid, 1992; Chen et al., 2016).

Thermal sensitivities are not always fixed and species with the capacity for acclimation may shift the temperature where their physiological rates are at a maximum across their ecological temperature range (Gabriel and Lynch, 1992; Dahlhoff and Somero, 1993). As such, acclimation can enhance fitness by ensuring that the optimal performance temperature overlaps with the temperatures prevailing in the environment (Gabriel and Lynch, 1992; Seebacher et al., 2010). Determining thermal sensitivities of $\dot{\mathrm{M}}_{\mathrm{O}_{2}}$ and heart rate in hybrids and parental pure species under a range of acclimation conditions could provide insight into the improved growth reported for many hybrids. For example, a lower metabolic sensitivity to environmental factors in hybrids may translate into lower long-term metabolic costs and higher abiotic tolerances as seen in comparisons between gastropod species from contrasting environmental habitats (Somero, 2002; Hawkins, 1995; Sokolova and Pörtner, 2003).

Traditionally, maximum temperatures are determined by exposing an animal to gradually increasing temperatures and measuring the temperature where an animal loses balance and mobility (Cowles and Bogert, 1944). This method provides limited additional information on the current physiological knowledge regarding improved performance of hybrids. Yet, understanding movement patterns and overall activity during warming may reveal a behavioral response by hybrids which results in a physiological advantage over pure species. Activity in gastropods indirectly affects fitness because of the high costs associated with locomotion and mucous production (Denny, 1980; Donovan and Carefoot, 1997). Lower activity in hybrids, for example, may result in an energetic advantage that could translate into faster growth.

Abalone are a marine mollusk (Cenni et al., 2009; Werner et al., 1995), and populations of the blacklip abalone Haliotis rubra (Leach, 1814) and the greenlip abalone H. laevigata (Donovan, 1808) occur on shallow reefs along the southern coasts of Australia (Shepherd, 1973). Their distribution ranges overlap and $\mathrm{H}$. rubra is found further south most commonly in water of 11 to $19{ }^{\circ} \mathrm{C}$ compared with most common temperatures of 12 to $23{ }^{\circ} \mathrm{C}$ for $\mathrm{H}$. laevigata (Shepherd, 1993). The two species typically differ in their microhabitat, whereby $H$. rubra inhabits sheltered areas of rocks while $H$. laevigata is often found on rocks exposed to rough waters. Additionally, the species show distinct behavioral differences, whereby $H$. rubra often wanders nocturnally to search for food, while $H$. laevigata may remain in one place for several years (Shepherd, 1973).

Naturally occurring hybrids between $H$. rubra and $H$. laevigata are rare (Brown and Murray, 1992; Brown, 1995) but it has become a key land-based aquaculture product in Australia because of its growth advantage (Guo, 2009; Hamilton et al., 2009; Li, 2008). The behavior of the hybrid is also better suited for culture because it does not escape grow-out tanks unlike its parental species H. rubra (Guo, 2009). Maximal growth, however, may still be impaired because of fluctuating environmental conditions prevailing on abalone farms (Morash and Alter, 2015). On most abalone farms, water temperature varies with the local environmental conditions and on some abalone farms oxygen levels frequently decrease to $70 \%$ air saturation $\left(\mathrm{O}_{2}\right.$ sat $)$ within grow-out tanks (K. Alter, unpubl. data).

This study measured physiological and behavioral responses of cultured $H$. rubra, H. laevigata, and their interspecies hybrid to an acute increase in temperature following acclimation to 16 or $23^{\circ} \mathrm{C}$ and to high $\left(100 \% \mathrm{O}_{2}\right.$ sat) or low $\left(70 \% \mathrm{O}_{2}\right.$ sat $)$ oxygen levels. The aim was to determine if differences in $\dot{\mathrm{M}}_{\mathrm{O}_{2}}$, heart rate and movement patterns of hybrids could help explain their growth heterosis relative to the pure parental species. It was hypothesized that hybrid abalone have a more consistent response to temperature, a higher thermal tolerance, and are less sensitive to changes in oxygen level than their parental pure species.

\section{Methods}

\subsection{Transport and acclimation in the laboratory}

Individually tagged (Hallprint tags) $\mathrm{H}$. rubra $(\mathrm{n}=72), \mathrm{H}$. laevigata ( $\mathrm{n}=75$ ) and their interspecies hybrid $(\mathrm{n}=72$, female $H$. rubra $\times$ male H. laevigata) were obtained from Jade Tiger Abalone (JTA) in Indented Head, Victoria, Australia. Individuals were sourced from one family to minimize effects of genetic variation. Abalone were age matched (22 months old) and differed significantly in total wet weight (WW) ( $\mathrm{p}<0.001$ for all types of abalone; $t$-test) and shell length (SL) ( $p<0.001$ for hybrids versus pure species, pure species not different to each other $\mathrm{p}>0.05$; $t$-test) (hybrid: $36.0 \pm 0.8 \mathrm{~g} \mathrm{WW}$ and $67.4 \pm 0.6 \mathrm{~mm}$ SL, $H$. rubra: $30.0 \pm 0.9 \mathrm{~g} \mathrm{WW}$ and $61.4 \pm 0.6 \mathrm{~mm} \mathrm{SL}, H$. laevigata $25.8 \pm 0.7 \mathrm{~g} \mathrm{WW}$ and $61.4 \pm 0.5 \mathrm{~mm} \mathrm{SL}$ ). Abalone were transferred to the laboratory at CSIRO in Hobart, Tasmania, according to standard industry shipping practices. In brief, animals were levered off the substrate in the grow-out tanks with a blunt spatula and transferred to purge tanks with a constant temperature of $16^{\circ} \mathrm{C}$ and no food supply. After two days the abalone were transferred into plastic bags filled with oxygen at $300 \%$ air saturation $\left(\mathrm{O}_{2}\right.$ sat), placed on ice in Styrofoam boxes and transported via air-freight to the laboratory in Hobart.

At the CSIRO laboratories, the abalone were housed in mixed groups in four separate aquaria (height: $20.0 \mathrm{~cm}$, diameter $70.5 \mathrm{~cm}$, water volume: $56.2 \mathrm{~L}$ ), with 13 to 18 individuals of $H$. rubra, $H$. laevigata and their interspecies hybrid in each. This allowed adjustment of later experimental conditions (see below) without requiring subsequent relocation of individuals. Recirculating seawater $\left(700 \mathrm{~L} ; 16\right.$ to $\left.17{ }^{\circ} \mathrm{C}\right)$ was bio-filtered, UV-treated, vigorously aerated, and changed by $50 \%$ every two days. Nitrogenous waste levels were measured daily with an accuracy of $0.25 \mathrm{mg} \mathrm{L}^{-1}$ for ammonia and nitrite levels and an accuracy of $5 \mathrm{mg} \mathrm{L}^{-1}$ for nitrate levels (API Saltwater Master Kit Test). Ammonia and nitrite levels did not reach $0.5 \mathrm{mg} \mathrm{L}^{-1}$ and nitrate levels remained under $25 \mathrm{mg} \mathrm{L}^{-1}$ except on two occasions when a measurement of $40 \mathrm{mg} \mathrm{L}^{-1}$ was recorded. Animals were fed with a commercial food pellet ad libitum and kept in constant darkness (as on commercial farm) to reduce disturbance caused by light. Feces and uneaten food were removed from the aquaria every morning. Temperature ( 16 to $17{ }^{\circ} \mathrm{C}$ ), oxygen level ( 91 to $99 \% \mathrm{O}_{2}$ sat) and salinity ( 31.3 to 34.4 ) were monitored daily. Abalone were given seven days to recover from transport prior to being exposed to acclimation conditions.

Subsequently, two aquaria with individuals of $H$. rubra, $H$. laevigata, and their interspecies hybrid were warmed to $23{ }^{\circ} \mathrm{C}$ at a rate of $1.5{ }^{\circ} \mathrm{C} \mathrm{d}^{-1}$. Additionally, the oxygen levels in one of the two aquaria per temperature $\left(16\right.$ and $\left.23{ }^{\circ} \mathrm{C}\right)$ were lowered to $70 \% \mathrm{O}_{2}$ sat $( \pm 2 \%$ $\mathrm{O}_{2}$ sat) at a rate of $4 \% \mathrm{O}_{2} \mathrm{sat} \mathrm{h}^{-1}$ using regulated nitrogen injection via solenoid valves (Atlantic, OxyGuard, Denmark). Abalone were held under these conditions (either 16 or $23{ }^{\circ} \mathrm{C}$ at each of 70 and $100 \% \mathrm{O}_{2}$ sat) for two weeks, which has been reported to be sufficient for warm-temperature acclimation in abalone (Dahlhoff and Somero, 1993). The respective oxygen contents of 70 and $100 \% \mathrm{O}_{2}$ sat were 6.9 and $9.8 \mathrm{mg} \mathrm{L}^{-1}$ at $16{ }^{\circ} \mathrm{C}$ and 6.0 and $8.6 \mathrm{mg} \mathrm{L}^{-1}$ at $23^{\circ} \mathrm{C}$. The $16{ }^{\circ} \mathrm{C}$ treatment served as a control group because this matched the culture temperature at JTA before transfer from the farm to the laboratory. The $23{ }^{\circ} \mathrm{C}$ temperature was selected as a treatment because it represents the highest temperature that abalone commonly experience at the farm during summer (A. Krsinich, JTA, pers. comm.). The control oxygen condition was $100 \% \mathrm{O}_{2}$ sat, while $70 \% \mathrm{O}_{2}$ sat was chosen because this oxygen level is towards the lowest level commonly experienced by abalone held at JTA (K. Alter, unpubl. data). Further, previous studies have shown that prolonged exposure of $H$. laevigata to oxygen levels 
lower than $70 \% \mathrm{O}_{2}$ sat at $18{ }^{\circ} \mathrm{C}$ caused increased mortality (Harris et al., 1999). Water quality assessment, light exposure and feeding practices were maintained as described above.

\subsection{Animal preparation and experimental design}

In the morning of each trial, the shells of seven abalone (mixture of hybrids and pure species) were brushed and blotted dry to minimize the presence of micro-organisms which may contribute to metabolic measurements. A small $<5 \mathrm{~mm}$ hole was drilled with a dremel in the shell above the heart. Care was taken to not damage the underlying pericardium during drilling and visual inspection of the heart confirmed that the tissue of all abalone used in experiments remained intact. A custom made wired biosensor (CSIRO and the University of Tasmania, Hellicar et al., 2015, see below) was attached flush with the shell using impregum ( $3 \mathrm{M}$ ESPE Impregum Soft). The animals were then transferred to individual respiration chambers at their respective acclimation conditions ( 16 or $23{ }^{\circ} \mathrm{C}$; 70 or $100 \% \mathrm{O}_{2}$ sat). Respiration chambers were PVC pipes with screw caps and glass bottoms (volume 1.2 L, height $6 \mathrm{~cm}$, diameter $16 \mathrm{~cm}$; 8 per trial) and were large enough for the abalone to move freely. Also the wires from the biosensor were long enough to not influence locomotion of the abalone. Each respirometer was equipped with a submersible pump $\left(3 \mathrm{~L} \mathrm{~min}^{-1}\right.$, Aquapro tabletop feature pump) to ensure that the water remained well mixed. Two cable glands in the screw caps hermetically sealed around the wires from the biosensor and an optical oxygen probe (Firesting, Germany). The chambers were placed in a water bath (total volume $520 \mathrm{~L}$ ) with a recirculating water supply. In the water bath, temperature was maintained using aquarium heaters (Weipro, titanium heater) and dissolved oxygen level was maintained by constantly bubbling water with air for the $100 \%$ $\mathrm{O}_{2}$ sat treatment or with regulated bursts of nitrogen for the $70 \% \mathrm{O}_{2}$ sat treatment (Atlantic, OxyGuard, Denmark). The abalone were left to recover for 20 to $22 \mathrm{~h}$ without food supply. Pre-experiments had shown that this time frame is sufficient for heart rate and $\dot{\mathrm{M}}_{\mathrm{O}_{2}}$ of $H$. rubra, $H$. laevigata, and their hybrid to return to resting rates. During this initial recovery period, the chambers were intermittently sealed hermetically for a maximum of 18 min per cycle, during which oxygen levels dropped by a maximum of $5 \% \mathrm{O}_{2}$ sat. Subsequently, the chambers were flushed with water from the water bath for $4.5 \mathrm{~min}$ to replenish oxygen levels back to test levels $\left(70 \%\right.$ or $100 \% \mathrm{O}_{2}$ sat). The experimental set-up was placed in a temperature controlled room. The room was dark except for visible red lighting beneath the chambers. The red lighting enabled video recording with two cameras (GoPro Hero 3) that were installed $30 \mathrm{~cm}$ below the water bath. Each camera captured four respiration chambers throughout the temperature challenge trials (see below).

Temperature challenge trials commenced $20-22 \mathrm{~h}$ after the abalone were placed in their individual respirometry chambers. These trials were conducted at the respective oxygen levels ( $70 \%$ or $100 \% \mathrm{O}_{2}$ sat). In addition, abalone acclimated to $70 \% \mathrm{O}_{2}$ sat were also tested at $100 \%$ $\mathrm{O}_{2}$ sat. For this oxygen condition (subsequently referred to as $70 / 100 \%$ $\mathrm{O}_{2}$ sat), the oxygen levels were acutely (within $20 \mathrm{~min}$ ) raised to $100 \%$ immediately before experiments commenced. During the thermal challenge, intermittent flow cycles were maintained as described for the initial recovery period. The cycles were upheld for $50 \mathrm{~min}$ after which temperatures were raised stepwise by $2{ }^{\circ} \mathrm{C}$ during a $15 \mathrm{~min}$ time interval and the protocol was repeated. This stepwise process continued until $31^{\circ} \mathrm{C}$ was reached. The experiments were terminated after the abalone had been exposed to $31^{\circ} \mathrm{C}$ for $50 \mathrm{~min}$. Animal movement, oxygen levels, heart rate, and water temperature were constantly measured throughout the experiments (see below). The abalone were removed from the chambers, rinsed with Milli-Q ${ }^{\circledR}$ water and individual whole animal, tissue and shell wet mass as well as shell length were de- termined. Between 9 and 12 individuals were tested per experimental treatment for each pure species and the interspecies hybrid.

\subsection{Analyses}

The cameras beneath the water bath took images every $10 \mathrm{~s}$ throughout the temperature challenge trials. Every tenth image from each experimental run were converted into an avi file. Individual animal movement (in shell length (SL) $[\mathrm{cm}] \mathrm{h}^{-1}$ ) was then calculated by manually tracking the shortest distance between the position of the snout of each individual between every frame (100 s) using the plugin MTrackJ for Image J (FIJI) (Schindelin et al., 2015; Myrick, 2009; Abramoff et al., 2004). The 15 min time interval between each fixed experimental temperature (during which temperature was raised by $2{ }^{\circ} \mathrm{C}$ ) was included in the movement analyses because individuals showed high activity during or immediately after this interval. Movement during the 15 min interval was added to the higher temperature that was reached after the interval.

Oxygen level was measured with an optical oxygen probe (Firesting, Germany) at a sampling rate of $1 \mathrm{~Hz}$ in each of the seven respiration chambers containing abalone. For each experimental run, one chamber without an abalone was included to serve as a control to account for background respiration by any micro-organisms in the seawater and on the surfaces of the respiration chambers. The optical oxygen probes were calibrated in air-saturated seawater for $100 \% \mathrm{O}_{2}$ sat and in sodium sulphite-saturated seawater for $0 \% \mathrm{O}_{2}$ sat. Temperature was measured (Firesting, Germany) at a sampling rate of $1 \mathrm{~Hz}$ in the common water bath and in one of the eight respiration chambers per experimental run. Oxygen consumption rate was determined for each individual abalone after 20 min exposure to each temperature. Blanks and individual $\dot{\mathrm{M}}_{\mathrm{O}_{2}}$ (in $\mu \mathrm{mol} \mathrm{g} \mathrm{WW}^{-1} \mathrm{~h}^{-1}$ ) were calculated from the linear decrease in $\%$ $\mathrm{O}_{2}$ sat measured in each respiration chamber during a sealed respirometry cycle across a $10 \mathrm{~min}$ recording according to Eq. (1):

$\mathrm{MO}_{2}=\frac{\Delta F \mathrm{O}_{2}}{\Delta t} \times\left(P_{\mathrm{B}},-, P_{\mathrm{S}}\right) \times \beta_{\mathrm{O}_{2}} \times$ Vol $\times 0.2093$

where $\Delta \mathrm{FO}_{2}$ is the difference of the fractional oxygen concentrations, $\Delta t$ is the difference in time (s), $P_{\mathrm{B}}$ is the barometric pressure $(\mathrm{kPa}), P_{\mathrm{S}}$ is the saturation vapor pressure of water $(\mathrm{kPa}), \beta_{\mathrm{O}_{2}}$ is the capacitance of water for oxygen, $\mathrm{Vol}$ is the chamber volume minus the abalone volume (L, assuming $1 \mathrm{~g}$ wet mass equals $1 \mathrm{ml}$ ), and 0.2093 is the fractional concentration of oxygen in water.

The wired biosensor that was fitted in the shell of each abalone allowed in situ real-time measurement of heart rate. An LED illuminated the heart with light which was then reflected and detected by a sensor unit, interfaced through PowerLab (ADInstruments, Australia), and recorded using the software LabChart 7 (ADInstruments, Australia). The signal from the heart was measured at a sampling rate of $400 \mathrm{~s}^{-1}$ for $5 \mathrm{~min}$ and was repeatedly cycled through the seven respiration chambers during the temperature challenge. Heart rate (in bpm) was then calculated by splitting the $5 \mathrm{~min}$ heart rate signal for each individual at each temperature into multiple $10 \mathrm{~s}$ sequences stepped at $5 \mathrm{~s}$ (Hellicar et al., 2015). Each sequence was analyzed using the autocorrelation method described in Hellicar et al. (2015). Median values across all sequences were used to estimate the entire heart rate sequence.

Upper critical temperatures of $\dot{\mathrm{M}}_{\mathrm{O}_{2}}$ and heart rate were determined via Arrhenius break-point temperature (ABT) plots. For this, the log of $\dot{\mathrm{M}}_{\mathrm{O}_{2}}$ and heart rate were calculated and plotted against temperature in $1000 \mathrm{~K}^{-1}$ (Fig. 1). The Arrhenius break-point temperature and corresponding heart rate and $\dot{\mathrm{M}}_{\mathrm{O}_{2}}$ maxima were then determined by least 


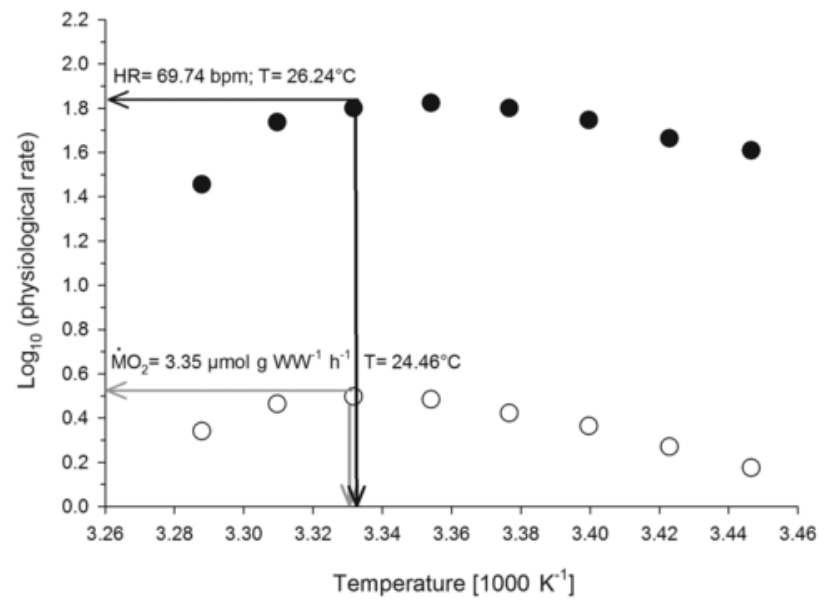

Fig. 1. Arrhenius break-point temperatures and corresponding physiological rates (heart rate $[\mathrm{bpm}]$, open circles; oxygen consumption rate $\left(\mathrm{M}_{\mathrm{O}_{2}}\right)\left[\mu \mathrm{mol} \mathrm{g} \mathrm{WW}^{-1} \mathrm{~h}^{-1}\right]$, closed circles) of one representative hybrid acclimated to $16{ }^{\circ} \mathrm{C}$ and $100 \% \mathrm{O}_{2}$ sat. Arrhenius break-point temperatures (vertical arrows) and corresponding (horizontal arrows) heart rate (grey) and $\mathrm{M}_{\mathrm{O}_{2}}$ (black) maxima were determined by fitting a broken-line function to the data.

squares regression (i.e. fitting a broken-line function to the data of each individual) (Muggeo, 2008).

$\mathrm{Q}_{10}$ values of $16^{\circ} \mathrm{C}$-acclimated abalone were calculated using $\dot{\mathrm{M}}_{\mathrm{O}_{2}}$ and heart rate data of each individual at 17 and $25{ }^{\circ} \mathrm{C}$ according to Eq. (2):

$Q_{10}=\left(\frac{R_{2}}{R_{1}}\right)^{\frac{10}{T_{2}-T_{1}}}$

where $R_{2}$ is the rate $\left(\dot{\mathrm{M}}_{\mathrm{O}_{2}}\right.$ or heart rate $)$ at high temperature $\left(T_{2}, 25^{\circ} \mathrm{C}\right)$ and $R_{1}$ is the rate at low temperature $\left(T_{1}, 17^{\circ} \mathrm{C}\right)$.

Pearson's correlation coefficients were calculated for $\dot{\mathrm{M}}_{\mathrm{O}_{2}}$ and heart rate data from 17 to $25{ }^{\circ} \mathrm{C}$ in the groups of abalone acclimated to $16{ }^{\circ} \mathrm{C}$ to determine if the two parameters correlate.

\subsection{Statistical analyses}

Pearson's correlation coefficients were calculated using Microsoft Excel 2010. A significant level of $p<0.05$ was selected for this and all following statistical analyses. Statistical tests to compare movement, slopes and intercepts of heart rate and $\dot{\mathrm{M}}_{\mathrm{O}_{2}}$ /temperature relationships, and ABTs and corresponding maximum heart rate and $\dot{\mathrm{M}}_{\mathrm{O}_{2}}$ values were performed with R v. 3.3.0 (R Core Team, 2016) using the R package nlme (Pinheiro et al., 2016). Pairwise multiple tests were carried out using the $\mathrm{R}$ package lsmeans and Bonferroni adjustments were applied to reduce the probability of false positives (type I error) (Lenth, 2016).

Movement, ABTs, and corresponding heart rate and $\mathrm{M}_{\mathrm{O}_{2}}$ maxima were compared between treatments and between types of abalone using generalized least squares (GLS) models. Heterogeneity of variances was accounted for in the model coefficient estimation. For movement data, a first-order autoregressive structure was assumed to deal with repeated measures and significant autocorrelation.

The effect of increasing temperature on heart rate and $\dot{\mathrm{M}}_{\mathrm{O}_{2}}$ of $16{ }^{\circ} \mathrm{C}$-acclimated abalone was tested with an ANCOVA. Linear mixed-effects models were fitted with abalone individuals as a random effect to take into account that measures of heart rate and $\dot{\mathrm{M}}_{\mathrm{O}_{2}}$ were taken repeatedly over time. This model also accounted for heteroscedasticity and significant autocorrelation. For heart rate data the mass of the individuals was used to weight the model fitting, taking into account the natural variations in heart rate occurring because of mass differences.

\section{Results}

For clarity throughout the results, acclimation conditions are stated in subscript following the type of abalone e.g. H. laevigata ${ }_{16 C_{70 / 100}}$ refers to $\mathrm{H}$. laevigata acclimated to $16{ }^{\circ} \mathrm{C}$ and $70 \% \mathrm{O}_{2}$ sat and measured at $100 \% \mathrm{O}_{2}$ sat. Subscripts without oxygen level are given in cases when no specification between oxygen acclimation is needed for clarification.

\subsection{Movement}

Experimental temperature had little influence on hybrid abalone movement, which was similar to $H$. laevigata but different to $H$. rubra (Fig. 2). Hybrid ${ }_{16 \mathrm{C}}$ moved similar distances irrespective of experimental temperature or oxygen level (on average $1.01 \pm 0.20 \mathrm{SL} \mathrm{h}^{-1}$ ) (Fig. $2 \mathrm{~A}$ ). Yet, hybrid ${ }_{23 \mathrm{C}}$ had a fluctuating movement pattern and travelled a 1 to 3 -fold longer distance at 25 and $29^{\circ} \mathrm{C}$ in comparison to 23 and $27{ }^{\circ} \mathrm{C}$. However, this pattern was only statistically significant between 23 and $25^{\circ} \mathrm{C}$ as well as 25 and $27^{\circ} \mathrm{C}$ in hybrid ${ }_{23 C_{1} 100}(\mathrm{p}<0.005)$ and hybrid $_{23 C_{2} 70 / 100}(\mathrm{p}<0.05)$ but not in hybrid ${ }_{23 C_{7} 70}(\mathrm{p}>0.05)$ (Fig. 2D). Similarly, $H$. laevigata ${ }_{16 \mathrm{C}}$ movement remained constant during temperature increase in all oxygen groups and averaged $0.43 \pm 0.09 \mathrm{SL} \mathrm{h}^{-1}$ (Fig. 2C). Haliotis laevigata ${ }_{23 C_{7} 70}$ had a fluctuating movement pattern in that distances travelled were three times longer at $25{ }^{\circ} \mathrm{C}$ in comparison to $23{ }^{\circ} \mathrm{C}(\mathrm{p}<0.05)$ and $27^{\circ} \mathrm{C}(\mathrm{p}<0.05)$ (Fig. 2F). Movement of $H$. laevigata $_{23 \mathrm{C}_{-} 70 / 100}$ averaged $1.21 \pm 0.30 \mathrm{SL} \mathrm{h}^{-1}$ at 25,27 and $29{ }^{\circ} \mathrm{C}$ and was 33-fold higher than movement at $23{ }^{\circ} \mathrm{C}(\mathrm{p}<0.02)$ (Fig. 2F). H. laevigata movement was generally similar to hybrids. Hybrid ${ }_{16 \mathrm{C}}$ moved on average twice the numerical distance of $H$. laevigata ${ }_{16 \mathrm{C}}$, but this trend was not statistically significant ( $p>0.05$; Fig. 2 A and C). Significantly longer distances were only observed for hybrid ${ }_{23 \mathrm{C}_{-} 100}$ in comparison to H. laevigata ${ }_{23 C_{-} 100}$ at $25{ }^{\circ} \mathrm{C}(\mathrm{p}<0.05)$ and $31^{\circ} \mathrm{C}(\mathrm{p}<0.05)$ and for hybrid $_{23 C_{-} 70 / 100}$ in comparison to H. laevigata $_{23 \mathrm{C}_{7} 70 / 100}$ at $23{ }^{\circ} \mathrm{C}(\mathrm{p}<0.05$, Fig. 2D and F).

In contrast to hybrids and $H$. laevigata, $H$. rubra showed a strong movement response with increasing temperature (Fig. 2B and E). For $H$. $\mathrm{rubra}_{16 \mathrm{C}}$, irrespective of oxygen level, movement increased significantly with temperature from 17 to $27{ }^{\circ} \mathrm{C}(\mathrm{p}<0.05)$ and decreased from 27 to $31{ }^{\circ} \mathrm{C}(\mathrm{p}<0.05)$ (Fig. 2B). Average distances moved near the acclimation temperature of $17^{\circ} \mathrm{C}$ were 7 and 8 times lower for $H_{\text {. }}$ rubra ${ }_{16 C_{2} 70 / 100}$ $\left(0.13 \pm 0.09 \mathrm{SL} \mathrm{h}^{-1}\right)$ in comparison to $H_{\text {. }}$ rubra $_{16 \mathrm{C}_{-} 100}(0.88 \pm 0.44 \mathrm{SL}$ $\left.\mathrm{h}^{-1}\right)$ and $H_{\text {. rubra }}$ 16C_70 $_{-}\left(1.09 \pm 0.41 \mathrm{SL} \mathrm{h}^{-1}\right)$, respectively, but the differences were not statistically significant $(\mathrm{p}>0.05)$. At other temperatures, $H$. rubra ${ }_{16 \mathrm{C}}$ movement was also similar between oxygen conditions and peaked at $27{ }^{\circ} \mathrm{C}$ with an average of $2.84 \pm 0.45 \mathrm{SL} \mathrm{h}^{-1}$ (Fig. 2B). A similar trend was seen for $H$. rubra ${ }_{23 C_{2} 100}$ with significantly lower movement at the acclimation temperature of $23{ }^{\circ} \mathrm{C}\left(0.52 \pm 0.18 \mathrm{SL} \mathrm{h}^{-1}\right)$ and peak movement at $29^{\circ} \mathrm{C}\left(1.81 \pm 0.40 \mathrm{SL} \mathrm{h}^{-1}, \mathrm{p}<0.02\right)$. In contrast, movement of $H_{\text {. rubra }}$ 23C_70 $_{2}$ and $H$. rubra ${ }_{23 C_{-70 / 100}}$ was similar across temperatures with average distances of $0.84 \pm 0.30 \mathrm{SL} \mathrm{h}^{-1}$ and $0.77 \pm 0.25$ $\mathrm{SL} \mathrm{h}^{-1}$, respectively (Fig. 2E). In comparison to $H$. rubra ${ }_{16 \mathrm{C}_{-} 100}$ and $H$. rubra $_{16 C_{-} 70}$, hybrids at the same acclimation condition moved shorter distances at $21{ }^{\circ} \mathrm{C}(\mathrm{p}<0.05), 25^{\circ} \mathrm{C}(\mathrm{p}<0.02)$ and $27^{\circ} \mathrm{C}(\mathrm{p}<0.05$;

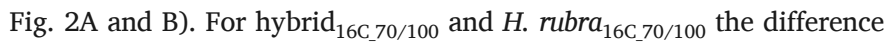
was only significant at $27^{\circ} \mathrm{C}(\mathrm{p}<0.01$; Fig. $2 \mathrm{~A}$ and B). Few statistical differences were observed between hybrid ${ }_{23 \mathrm{C}}$ and $\mathrm{H}$. $\mathrm{rubra}_{23 \mathrm{C}}$. Haliotis rubra ${ }_{23 C_{-} 100}$ moved 3-fold longer distances at $27{ }^{\circ} \mathrm{C}(\mathrm{p}<0.02)$ and H. rubra $_{23 C_{-} 70 / 100}$ moved 2-fold shorter distances at $25{ }^{\circ} \mathrm{C}(\mathrm{p}<0.05)$ in comparison to hybrids at the same acclimation condition (Fig. 2D and E). 

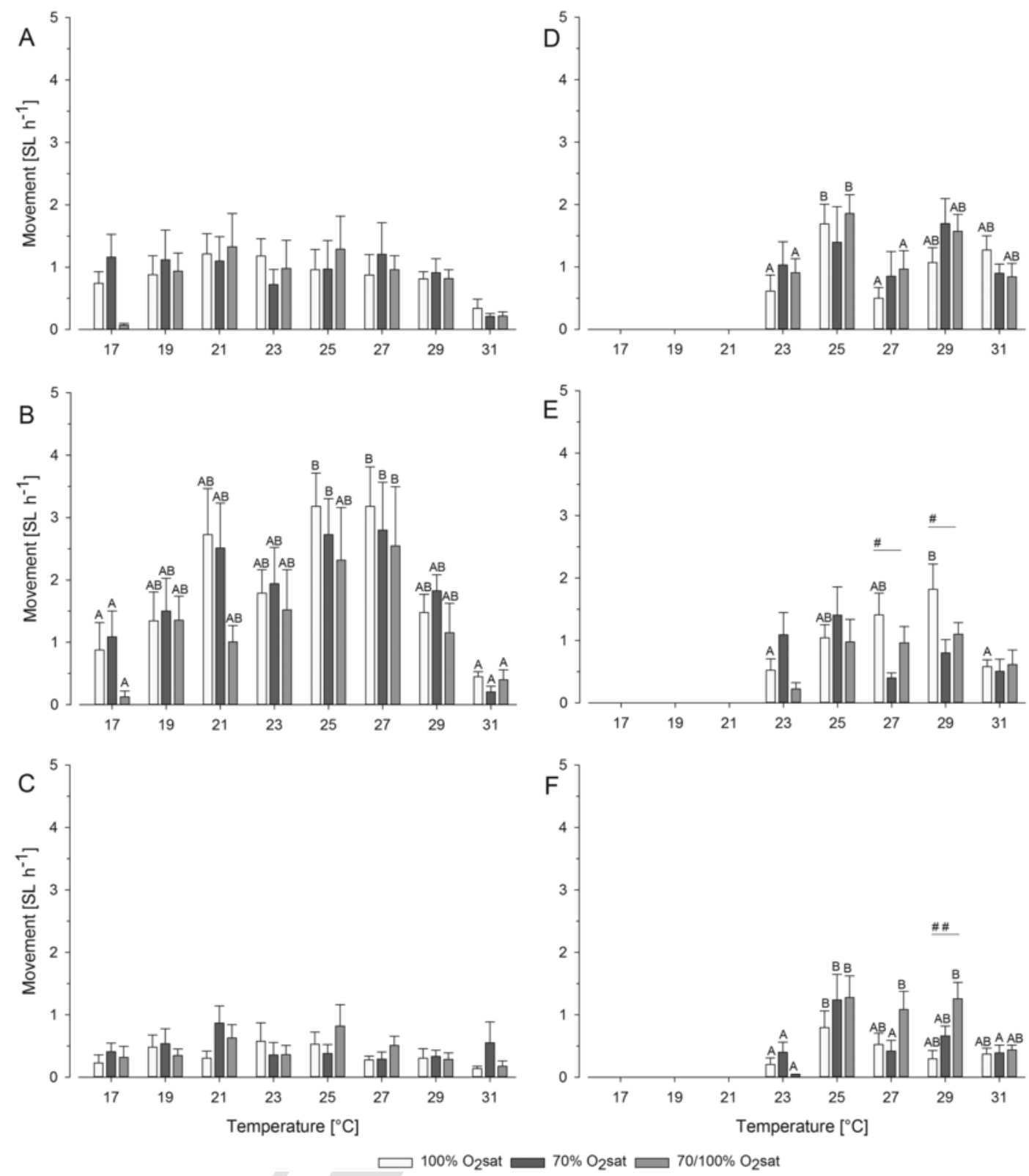

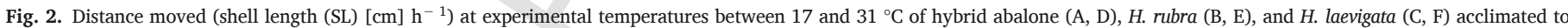

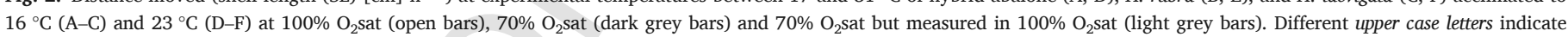

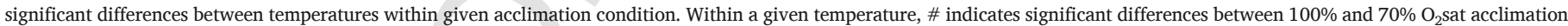
and \#\# indicates significant differences between $100 \%$ and $70 / 100 \% \mathrm{O}_{2}$ sat (abalone acclimated to $70 \% \mathrm{O}_{2}$ sat but measured in $100 \% \mathrm{O}_{2}$ sat) acclimation. Mean \pm SE. $\mathrm{n}=9-12$.

\subsection{Physiological rate increments with temperature ramping}

Heart rate and $\dot{\mathrm{M}}_{\mathrm{O}_{2}}$ of hybrids and both pure species in all acclimation groups responded with a similar pattern to experimental temperature (example in Fig. 1). Indeed, $\dot{\mathrm{M}}_{\mathrm{O}_{2}}$ was positively correlated with heart rate in all acclimation groups of hybrid ${ }_{16 \mathrm{C}}$ as well as both pure species $_{16 \mathrm{C}}$ (Pearson's correlation coefficient, $\mathrm{p}<0.01$ ) (Table 1). Both physiological parameters increased with increasing temperatures up to a temperature between 25 and $29{ }^{\circ} \mathrm{C}$ and decreased with further increases in temperature. Given that in some cases only two data points (at 23 and $25{ }^{\circ} \mathrm{C}$ ) were available for analysis for the $23^{\circ} \mathrm{C}$-acclimated abalone, these groups were not analyzed further. Thus, rate increases were analyzed only for $16{ }^{\circ} \mathrm{C}$-acclimated abalone at temperatures between 17 and $25{ }^{\circ} \mathrm{C}$.

\subsubsection{Heart rate}

The influence of experimental temperature on heart rate was similar for all three types of abalone in that increasing temperatures from 17 to $25{ }^{\circ} \mathrm{C}$ resulted in a 1 to 2 -fold increase in heart rate (Fig. 3A-C). Further, a significant interaction between oxygen level and experimental temperature was seen in all three types of abalone. For hybrids, exposure to an acute increase in oxygen (i.e. from $70 \%$ to $100 \% \mathrm{O}_{2}$ sat) resulted in a significantly higher heart rate/temperature intercept in comparison to hybrid ${ }_{16 C_{-} 100}(\mathrm{p}<0.0001)$ (Fig. 3A). Yet, heart rate/temperature intercepts for $H$. rubra ${ }_{16 \mathrm{C}}$ and $H$. laevigata ${ }_{16 \mathrm{C}}$ under increased oxygen were significantly higher than those of both $100 \% \mathrm{O}_{2}$ sat $(\mathrm{p}<0.02)$ and $70 \% \mathrm{O}_{2}$ sat $(\mathrm{p}<0.02$ ) acclimated individuals (Fig. 3B and C). Regression equations for heart rate/temperature slopes for all acclimation conditions and types of abalone are given in Table 1. 
Table 1

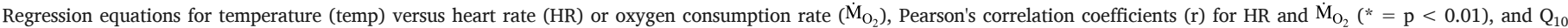

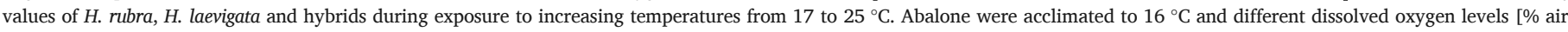
saturation $\left(\mathrm{O}_{2}\right.$ sat $\left.)\right]$. Mean \pm SE. $\mathrm{n}=9-12$.

\begin{tabular}{|c|c|c|c|c|c|c|}
\hline \multirow[t]{2}{*}{ Type of abalone } & \multirow[t]{2}{*}{ Oxygen level } & \multicolumn{3}{|l|}{ Equation } & \multicolumn{2}{|l|}{$\mathrm{Q}_{10}$} \\
\hline & & Heart rate & $\dot{\mathrm{M}}_{\mathrm{O}_{2}}$ & $\mathrm{r}$ & Heart rate & $\dot{\mathrm{M}}_{\mathrm{O}_{2}}$ \\
\hline \multirow[t]{3}{*}{ Hybrid } & 100 & $\mathrm{HR}=$ temp $\times 3.49-23.90$ & $\dot{\mathrm{M}}_{\mathrm{O}_{2}}=$ temp $\times 0.22-2.35$ & $+0.867^{*}$ & $1.99 \pm 0.07$ & $2.66 \pm 0.24$ \\
\hline & 70 & $\mathrm{HR}=$ temp $\times 2.94-12.33$ & $\dot{\mathrm{M}}_{\mathrm{O}_{2}}=$ temp $\times 0.18-1.70$ & $+0.873^{*}$ & $1.81 \pm 0.08$ & $2.52 \pm 0.23$ \\
\hline & $70 / 100$ & $\mathrm{HR}=$ temp $\times 2.56-4.39$ & $\dot{\mathrm{M}}_{\mathrm{O}_{2}}=$ temp $\times 0.19-1.64$ & $+0.854 *$ & $1.74 \pm 0.03$ & $2.44 \pm 0.14$ \\
\hline \multirow[t]{3}{*}{ H. rubra } & 100 & $\mathrm{HR}=$ temp $\times 2.90-12.58$ & $\dot{\mathrm{M}}_{\mathrm{O}_{2}}=$ temp $\times 0.20-1.76$ & $+0.845^{*}$ & $1.95 \pm 0.13$ & $2.35 \pm 0.11$ \\
\hline & 70 & $\mathrm{HR}=$ temp $\times 3.21-13.52$ & $\dot{\mathrm{M}}_{\mathrm{O}_{2}}=$ temp $\times 0.19-2.17$ & $+0.686^{*}$ & $2.14 \pm 0.14$ & $2.89 \pm 0.32$ \\
\hline & $70 / 100$ & $\mathrm{HR}=\mathrm{temp} \times 2.20+8.96$ & $\dot{\mathrm{M}}_{\mathrm{O}_{2}}=$ temp $\times 0.17-0.89$ & $+0.796^{*}$ & $1.61 \pm 0.05$ & $1.93 \pm 0.10$ \\
\hline \multirow[t]{3}{*}{ H. laevigata } & 100 & $\mathrm{HR}=\mathrm{temp} \times 3.04-20.95$ & $\dot{\mathrm{M}}_{\mathrm{O}_{2}}=$ temp $\times 0.17-1.71$ & $+0.676^{*}$ & $2.08 \pm 0.10$ & $2.73 \pm 0.23$ \\
\hline & 70 & $\mathrm{HR}=$ temp $\times 3.00-14.06$ & $\mathrm{M}_{\mathrm{O}_{2}}=$ temp $\times 0.18-1.58$ & $+0.717^{*}$ & $1.87 \pm 0.06$ & $2.65 \pm 0.28$ \\
\hline & $70 / 100$ & $\mathrm{HR}=$ temp $\times 2.45-1.95$ & $\dot{\mathrm{M}}_{\mathrm{O}_{2}}=$ temp $\times 0.15-1.05$ & $+0.770^{*}$ & $1.62 \pm 0.09$ & $2.08 \pm 0.18$ \\
\hline
\end{tabular}

N.B. $70 / 100=$ abalone acclimated to $70 \% \mathrm{O}_{2}$ sat and measured in $100 \% \mathrm{O}_{2}$ sat.
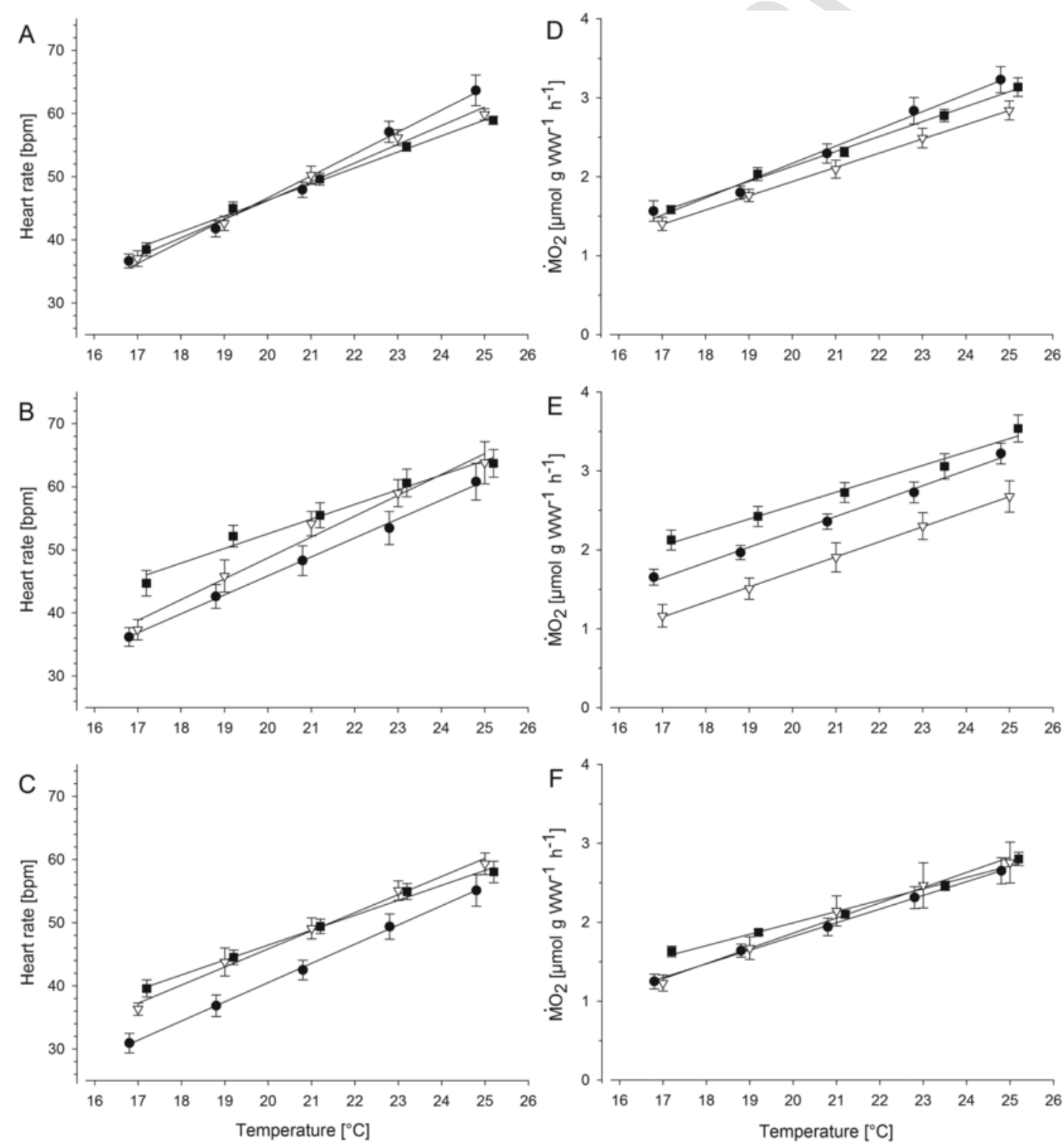

- $16^{\circ} \mathrm{C}$ and $100 \% \mathrm{O}_{2}$ sat $\nabla \quad 16^{\circ} \mathrm{C}$ and $70 \% \mathrm{O}_{2}$ sat $16^{\circ} \mathrm{C}$ and $70 / 100 \% \mathrm{O}_{2}$ sat

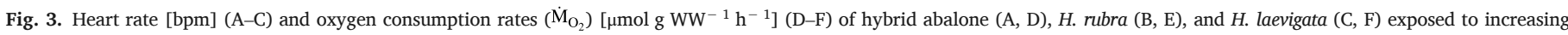

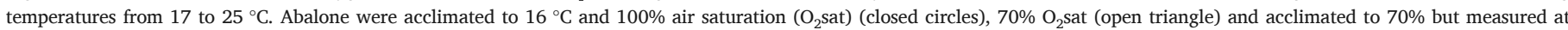
$100 \% \mathrm{O}_{2}$ sat (closed square). Symbols are offset for visual clarity of error bars. Equations for regression lines are stated in Table $1 . \mathrm{n}=9-12$. 


\subsubsection{Oxygen consumption rate}

Acclimation condition had a different effect on $\dot{\mathrm{M}}_{\mathrm{O}_{2}}$ between types of abalone. For all hybrid ${ }_{16 \mathrm{C}}$ abalone, $\dot{\mathrm{M}}_{\mathrm{O}_{2}}$ doubled during exposure to increasing experimental temperatures from 17 to $25^{\circ} \mathrm{C}$ (p $<0.001$ ) (Fig. 3D; Table 1). Oxygen level, however, had no influence on the relationship. This result was similar to that observed for $H_{\text {. laevigata }}$. $_{\text {(6ig. }}$ (F), but different to that for $H$. rubra ${ }_{16 \mathrm{C}}$ (Fig. 3E). Oxygen level had a significant influence on the $\dot{\mathrm{M}}_{\mathrm{O}_{2}}$ /temperature slope of $H$. rubra ${ }_{16 \mathrm{C}}(\mathrm{p}=0.001)$. The intercept was significantly higher in $H_{\text {. }}$ rubra $_{16 \mathrm{C}_{70 / 100}},(\mathrm{p}<0.05)$ and lower in $H$. rubra ${ }_{16 \mathrm{C} 70}$ ( $\mathrm{p}<0.02$ ) compared to H. rubra 16__100 $_{\text {(Fig. }}$ $3 \mathrm{E}$ ). Regression equations for $\dot{\mathrm{M}}_{\mathrm{O}_{2}}$ /temperature slopes for all acclimation conditions and types of abalone are given in Table 1.
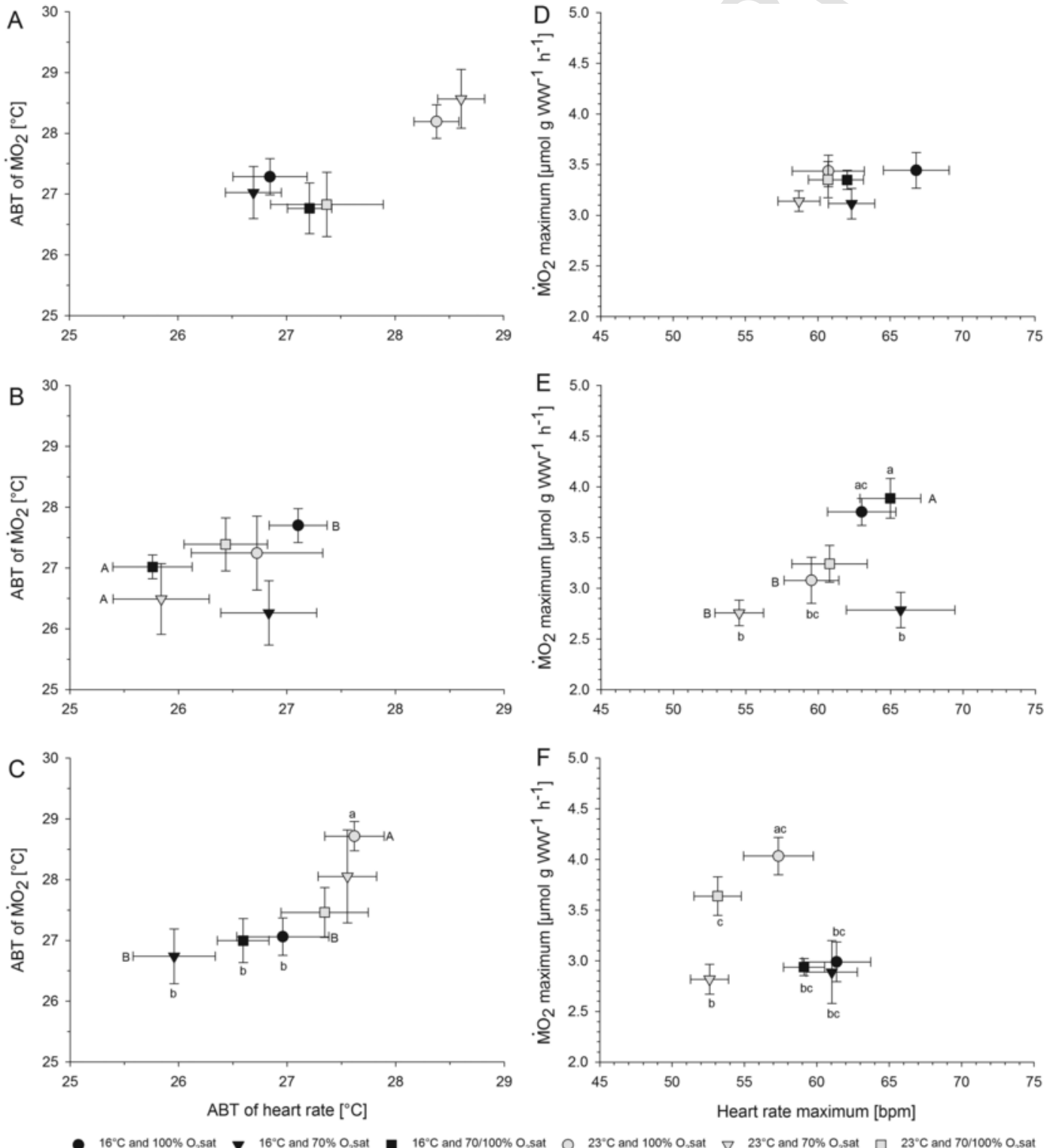

$16^{\circ} \mathrm{C}$ and $100 \% \mathrm{O}_{2}$ sat $>16^{\circ} \mathrm{C}$ and $70 \% \mathrm{O}_{2}$ sat

\subsection{Arrhenius break-points}

\subsubsection{Arrhenius break-point temperatures}

For hybrids, ABTs of heart rate and $\dot{\mathrm{M}}_{\mathrm{O}_{2}}$ were generally higher in $23{ }^{\circ} \mathrm{C}$-acclimated abalone compared with $16^{\circ} \mathrm{C}$-acclimated abalone, a pattern that was similar to $H$. laevigata but different to $H$. rubra (Fig. 4; Table 2). Arrhenius break-point temperatures of heart rate and $\dot{\mathrm{M}}_{\mathrm{O}_{2}}$ in hybrid ${ }_{23 \mathrm{C} 100}$ and hybrid ${ }_{23 \mathrm{C} 70}$ were between 28 and $29{ }^{\circ} \mathrm{C}$ and those of hybrids at all other acclimation groups were between 26 and $28{ }^{\circ} \mathrm{C}$. The difference was not statistically significant between acclimation groups within hybrids ( $\mathrm{p}>0.05$ ) (Fig. 4A; Table 2). However, the heart rate $\mathrm{ABTs}$ of hybrid $\mathrm{23}_{2100}$ and hybrid ${ }_{23 \mathrm{C}_{70}}$ were significantly higher in comparison with those of $H_{\text {. }}$ laevigata $_{23 \mathrm{C}_{-} 100}$ and $\mathrm{H}$. laevigata $_{23 \mathrm{C} 70}(\mathrm{p}<0.001)$ (Fig. 4A-C; Table 2). For $H_{\text {. laevigata }} 23 \mathrm{C}$, heart rate and $\dot{\mathrm{M}}_{\mathrm{O}_{2}}$ ABTs were between 27 and $29^{\circ} \mathrm{C}$ and lower in $\mathrm{H}$. laevigata $_{16 \mathrm{C}}$ with values between 26 and $27^{\circ} \mathrm{C}$. The differences were signifi-
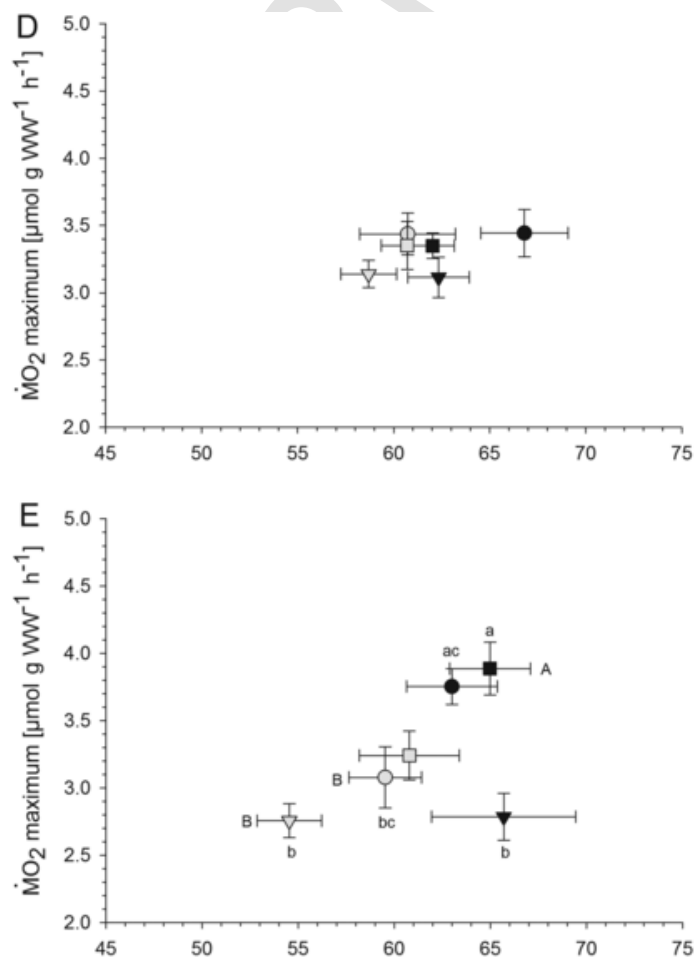

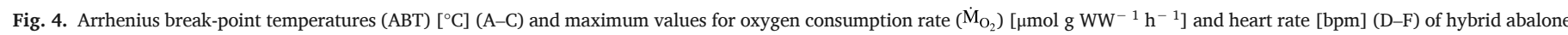

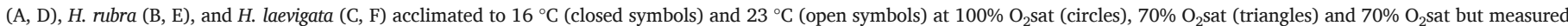

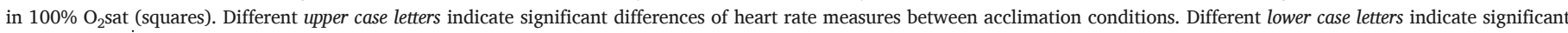
differences of $\dot{\mathrm{M}}_{\mathrm{O}_{2}}$ measures between acclimation conditions. Mean \pm SE. $\mathrm{n}=9-12$. 
Table 2

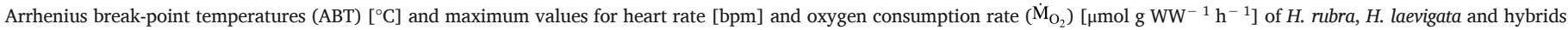
acclimated to two temperatures $\left[{ }^{\circ} \mathrm{C}\right]$ and three dissolved oxygen conditions $\left[\%\right.$ air saturation $\left(\mathrm{O}_{2}\right.$ sat $\left.)\right]$. Mean \pm SE. $\mathrm{n}=9-12$.

\begin{tabular}{|c|c|c|c|c|c|c|}
\hline \multirow[t]{2}{*}{ Species } & \multicolumn{2}{|l|}{ Acclimation } & \multicolumn{2}{|l|}{$\mathrm{ABT}$} & \multicolumn{2}{|l|}{ Maximum value } \\
\hline & Temperature $\left[{ }^{\circ} \mathrm{C}\right]$ & Oxygen level $\left[\% \mathrm{O}_{2}\right.$ sat $]$ & Heart rate $\left[{ }^{\circ} \mathrm{C}\right]$ & $\dot{\mathrm{M}}_{\mathrm{O}_{2}}\left[{ }^{\circ} \mathrm{C}\right]$ & Heart rate $[\mathrm{bpm}]$ & $\dot{\mathrm{M}}_{\mathrm{O}_{2}}\left[\mu \mathrm{mol} \mathrm{g} \mathrm{WW}{ }^{-1} \mathrm{~h}^{-1}\right]$ \\
\hline \multirow[t]{6}{*}{ Hybrid } & 16 & 100 & $26.8 \pm 0.4$ & $27.3 \pm 0.3$ & $67.8 \pm 2.3$ & $3.4 \pm 0.2$ \\
\hline & & 70 & $26.7 \pm 0.3$ & $27.0 \pm 0.4$ & $62.3 \pm 1.6$ & $3.1 \pm 0.1$ \\
\hline & & $70 / 100$ & $27.2 \pm 0.2$ & $26.8 \pm 0.4$ & $62.0 \pm 1.1$ & $3.3 \pm 0.1$ \\
\hline & 23 & 100 & $28.4 \pm 0.2$ & $28.2 \pm 0.3$ & $60.7 \pm 2.5$ & $3.4 \pm 0.2$ \\
\hline & & 70 & $28.3 \pm 0.3$ & $28.6 \pm 0.5$ & $59.7 \pm 1.7$ & $3.1 \pm 0.1$ \\
\hline & & $70 / 100$ & $27.4 \pm 0.5$ & $26.8 \pm 0.5$ & $60.7 \pm 1.4$ & $3.4 \pm 0.2$ \\
\hline \multirow[t]{6}{*}{ H. rubra } & 16 & 100 & $27.1 \pm 0.3$ & $27.7 \pm 0.3$ & $63.0 \pm 2.4$ & $3.8 \pm 0.1$ \\
\hline & & 70 & $26.8 \pm 0.4$ & $26.3 \pm 0.5$ & $65.7 \pm 3.8$ & $2.8 \pm 0.2$ \\
\hline & & $70 / 100$ & $25.8 \pm 0.4$ & $27.0 \pm 0.2$ & $65.0 \pm 2.1$ & $3.9 \pm 0.2$ \\
\hline & 23 & 100 & $26.7 \pm 0.6$ & $27.0 \pm 0 / 6$ & $59.5 \pm 1.9$ & $3.0 \pm 0.2$ \\
\hline & & 70 & $25.8 \pm 0.4$ & $26.4 \pm 0.5$ & $54.5 \pm 1.7$ & $2.6 \pm 0.1$ \\
\hline & & $70 / 100$ & $26.4 \pm 0.4$ & $27.4 \pm 0.4$ & $60.8 \pm 2.6$ & $3.2 \pm 0.2$ \\
\hline \multirow{6}{*}{$\begin{array}{l}H . \\
\text { laevigata }\end{array}$} & 16 & 100 & $27.0 \pm 0.4$ & $27.1 \pm 0.3$ & $61.4 \pm 2.4$ & $3.0 \pm 0.2$ \\
\hline & & 70 & $26.0 \pm 0.4$ & $26.4 \pm 0.5$ & $61.0 \pm 1.8$ & $2.9 \pm 0.3$ \\
\hline & & $70 / 100$ & $26.6 \pm 0.2$ & $27.0 \pm 0.4$ & $59.1 \pm 1.4$ & $2.9 \pm 0.1$ \\
\hline & 23 & 100 & $27.6 \pm 0.2$ & $28.5 \pm 0.3$ & $55.6 \pm 2.2$ & $3.9 \pm 0.2$ \\
\hline & & 70 & $27.6 \pm 0.3$ & $28.1 \pm 0.8$ & $52.6 \pm 1.3$ & $2.8 \pm 0.1$ \\
\hline & & $70 / 100$ & $27.3 \pm 0.4$ & $27.6 \pm 0.4$ & $53.1 \pm 1.6$ & $3.6 \pm 0.2$ \\
\hline
\end{tabular}

N.B. $70 / 100=$ abalone acclimated to $70 \% \mathrm{O}_{2}$ sat and measured in $100 \% \mathrm{O}_{2}$ sat.

cant between $H$. laevigata ${ }_{23 \mathrm{C}_{-} 100}$ and $H_{\text {. }}$ laevigata $_{16 \mathrm{C}_{-} 100}(\mathrm{p}<0.001)$ as well as $H_{\text {. laevigata }}$ 16__70 $(\mathrm{p}<0.02)$ (Fig. 4C; Table 2).

In contrast to hybrids and $H$. laevigata, higher acclimation temperatures did not result in higher ABTs for $\mathrm{H}$. rubra (Fig. 4; Table 2). Arrhenius break-point temperatures for $\dot{\mathrm{M}}_{\mathrm{O}_{2}}$ were similar between all acclimation conditions and ranged from 25 to $28{ }^{\circ} \mathrm{C}$ (Fig. 4B; Table 2). Heart rate $\mathrm{ABT}$ ranged between 26 and $27^{\circ} \mathrm{C}$ with significantly lower values in $H_{\text {. }}$ rubra $_{16 \mathrm{C}_{-} 70 / 100}(\mathrm{p}<0.005)$ and H. rubra $_{23 \mathrm{C}_{-} 70}(\mathrm{p}<0.01)$ in comparison to $H$. $r u b r a_{16 C_{-} 100}$ (Fig. 4B; Table 2).

\subsubsection{Heart rate and $\dot{\mathrm{M}}_{\mathrm{o}_{2}}$ maxima}

Hybrids had similar $\dot{\mathrm{M}}_{\mathrm{O}_{2}}$ maxima (average $3.3 \pm 0.1 \mu \mathrm{mol} \mathrm{g} \mathrm{WW}^{-1} \mathrm{~h}^{-1}$ ) and heart rate maxima (average $61.9 \pm 0.8 \mathrm{bpm})$ irrespective of acclimation oxygen level and temperature ( $>0.05$ ) (Fig. 4D; Table 2), which was in contrast to both pure species. In general, heart rate maxima of $H$. rubra ${ }_{23 \mathrm{C}}$ and $H$. laevigata $_{23 \mathrm{C}}$ tended to be $\sim 10 \%$ lower in comparison to $H$. rubra $a_{16 \mathrm{C}}$ and $H$. laevigata ${ }_{16 \mathrm{C}}$ (Fig. $4 \mathrm{E}$ and $\mathrm{F}$; Table 2). The difference, however, was only statistically significant between $H$. rubra ${ }_{23 C_{70}}$ and $H$. rubra $_{16 C_{-} 70 / 100}(\mathrm{p}<0.002)$ (Fig. 4E; Table 2). Maximum $\mathrm{M}_{\mathrm{O}_{2}}$ values showed a different trend between the two pure species in that $H$. rubra had highest $\dot{\mathrm{M}}_{\mathrm{O}_{2}}$ maxima when acclimated to $16^{\circ} \mathrm{C}$ but $\mathrm{H}$. laevigata had highest $\dot{\mathrm{M}}_{\mathrm{O}_{2}}$ maxima when acclimated to $23{ }^{\circ} \mathrm{C}(\mathrm{H}$. rubra $_{16 \mathrm{C} \_100}=3.8 \pm 0.1 \mu \mathrm{mol} \mathrm{g} \mathrm{WW}^{-1} \mathrm{~h}^{-1}, \quad H . \quad$ laevigata $\left._{23 \_100}=4.0 \pm 0.2 \mu \mathrm{mol} \mathrm{g} \mathrm{WW}{ }^{-1} \mathrm{~h}^{-1}\right)($ Fig. 4E and F; Table 2).

\section{Discussion}

The present study was conducted to determine behavioral and physiological responses of hybrid abalone that may explain their growth heterosis in comparison to the pure parental species. Movement of hybrids and $H$. laevigata was not affected by oxygen levels and temperature, while $H$. rubra showed a strong thermal response (Fig. 2). Heart rate and $\dot{\mathrm{M}}_{\mathrm{O}_{2}}$ of hybrids remained similar irrespective of oxygen level while pure species adjusted both parameters (Fig. 3). Arrhenius break-point temperatures of hybrids and $\mathrm{H}$. laevigata were higher when acclimated to $23{ }^{\circ} \mathrm{C}$ compared with $16{ }^{\circ} \mathrm{C}$ which was not observed for $\mathrm{H}$. rubra (Fig. 4A-C). When comparing maximum heart rate and $\dot{\mathrm{M}}_{\mathrm{O}_{2}}$ values, those of hybrids were more stable than those of both pure species
(Fig. 4D-F). While the differences detected between hybrids and pure species were minor, they do support the original hypothesis that hybrids are less sensitive to changes in environmental conditions. This tendency for environmental resilience may ultimately contribute to the growth advantage of hybrids over long grow-out periods in the environmentally unstable aquaculture environment. It should be considered, however, that abalone used in the present study were sourced from one family; this minimizes genetic variation when comparing across treatments, but does not allow assessments of the breadth of variability across the broader population. Presumably the advantages must be limited in the natural environment because hybrid prevalence is low.

Movement in gastropods is energetically expensive due to the high costs associated with crawling and mucous production (Robinson et al., 2013; Werner et al., 1995; Denny, 1980; Donovan and Carefoot, 1997). Therefore, it is assumed to mainly occur because of disturbance or to find food (Robinson et al., 2013; Werner et al., 1995). Since food was not provided during this experiment, the differences in movement are likely to be associated with the treatment challenges. Increased movement as a response to thermal stress requires that energy is directed towards muscular work and mucous production and away from growth. Thus, the consistent shorter distance travelled across temperatures in hybrids may translate to a growth advantage under fluctuating thermal conditions compared with $H$. rubra but not compared with $H$. laevigata (Fig. 2). Without thermal stress, longer distances travelled can be beneficial to exploit resources and can overrule the costs of transport (Cenni et al., 2009). This may lead to a growth advantage for the hybrid in comparison to the more stationary $H$. laevigata. These behaviors may be particularly beneficial in artificial environments, where abalone do not have to forage because sinking food pellets are used in high quantities and negative effects of movement such as a higher risk of predation due to higher visibility are minimized (Cenni et al., 2009). Indeed, cultured hybrid abalone have a higher food intake than $H$. laevigata (Currie et al., 2016). Hence, the longer distance travelled in hybrids may add to their growth advantage in comparison to the slower growing and less active H. laevigata.

Heart rate and metabolic rate of hybrid abalone were consistently more stable across temperatures and oxygen saturations than the pure species, suggesting that hybrids are less sensitive to changes in oxygen level. In addition, the higher ABTs in hybrids (and H. laevigata) accli- 
mated to $23{ }^{\circ} \mathrm{C}$ versus those acclimated to $16^{\circ} \mathrm{C}$ suggest that they were better able to acclimate to the higher experimental temperature compared to $H$ rubra. In combination, these results may illustrate an energetic advantage for the hybrid and ultimately contribute to higher growth. First, sensitivity to oxygen is energetically expensive because of long-term costs associated with repair and replacement of oxygen damaged macromolecules (Hawkins and Day, 1999; Somero, 2002). Hence, the protein turnover is reduced in less sensitive individuals, which leads to lower energy requirements and results in a greater potential for growth (Hawkins and Day, 1999; Toro et al., 1996). Second, thermal acclimation leads to adjustments on the cellular level which are initially costly but ultimately result in a shift of the optimum and maximum performance temperatures. As a consequence, more energy is available in the long term for growth under the prevailing thermal conditions (Newell and Kofoed, 1977; Beiras et al., 1995; Sokolova et al., 2012).

The constant heart rate and $\dot{\mathrm{M}}_{\mathrm{O}_{2}}$ at different oxygen levels in hybrids does not necessarily indicate that hybrids were not responding to oxygen levels. In H. iris (Martyn, 1784), for example, heart rate also remained stable after exposure to environmental hypoxia (Ragg and Taylor, 2006). It was shown, however, that blood flow in $H$. iris increased 2.7-fold above rates of unstressed individuals in normoxia and it was hypothesized that this resulted from an increased stroke volume (Ragg and Taylor, 2006). Blood flow was not measured in the present study, but it is possible that elevated stroke volume contributed to the more stable heart rate seen in hybrids. Yet, it was further suggested by Ragg and Taylor (2006) that the increase in blood flow seen in H. iris would promote an increase in $\dot{\mathrm{M}}_{\mathrm{O}_{2}}$, which was not the case for hybrids in the present study. Future work including simultaneous measurements of heart rate, cardiac output, and $\dot{\mathrm{M}}_{\mathrm{O}_{2}}$ is needed to clarify whether hybrids adjust stroke volume to maintain $\dot{\mathrm{M}}_{\mathrm{O}_{2}}$ at varying oxygen levels or if they are indeed unaffected by the oxygen levels used here.

Hybrids and $H$. laevigata but not $H$. rubra showed thermal acclimation capacity. The ability to thermally acclimate is strongly dependent on genetics and correlates with the biogeographical distribution in congeners of abalone (Dahlhoff and Somero, 1993; Liang et al., 2014). For example, five American abalone species could only acclimate their mitochondrial respiration when exposed to temperatures that they commonly experience in nature. The five species did not acclimate to temperature extremes that occur in their full biogeographical distribution (Dahlhoff and Somero, 1993). In line with these observations, it is possible that $H$. rubra was not able to acclimate to $23^{\circ} \mathrm{C}$ because this is outside the temperature range where this species is commonly found - 11 and $19{ }^{\circ} \mathrm{C}$ (Shepherd, 1973). In contrast, $H$. laevigata commonly experiences temperatures up to $23^{\circ} \mathrm{C}$, which may have enabled it to acclimate to this temperature in the present study. The fact that the hybrid also showed acclimation capacity at $23{ }^{\circ} \mathrm{C}$ suggests that it may have inherited the heat tolerance trait of $\mathrm{H}$. laevigata. Similar results were observed in cultured Chinese abalone, in which the interspecies hybrid between $H$. discus hannai (Reeve, 1846) and H. gigantea (Gmelin, 1791) inherited the thermal tolerance trait of the more heat tolerant $H$. gigantea (Liang et al., 2014).

Arrhenius break-point temperatures for heart rate and $\dot{\mathrm{M}}_{\mathrm{O}_{2}}$ varied by $4{ }^{\circ} \mathrm{C}$, between 25 and $29^{\circ} \mathrm{C}$, between types of abalone in this study. While there is some evidence from other studies that thermal tolerance of abalone is size dependent (Steinarsson and Imsland, 2003; Searle et al., 2006), the size range used in the present study spanned only 61 to $67 \mathrm{~mm} \mathrm{SL}$, precluding a comprehensive examination of the influence of size on thermal tolerance. The variation of $4{ }^{\circ} \mathrm{C}$ in ABTs between types of abalone in this study is greater than the slightly different upper critical temperatures reported previously for the pure species, $H$. rubra - $26.9^{\circ} \mathrm{C}$ and $\mathrm{H}$. laevigata $-27.5^{\circ} \mathrm{C}$, measured as the temperature at which the abalone detached from the substrate (Gilroy and Edwards, 1998). This suggests that ABTs for heart rate and $\dot{M}_{\mathrm{O}_{2}}$ may represent more sensitive measures of heat tolerance in abalone compared with upper critical temperature measurements. This conclusion is in accordance with similar observations between heart rate ABTs and traditional upper critical temperature experiments in Chinese abalone, $H$ discus hannai, $H$. gigantea, and their interspecies hybrid (Chen et al., 2016). Further, the ABTs determined for abalone in the present study are only 2 to $6{ }^{\circ} \mathrm{C}$ above summer sea temperatures of $23^{\circ} \mathrm{C}$ occurring in natural habitats of their founders, rendering abalone, especially $H$. rubra, vulnerable to future climate change-induced temperature increases (Fordham et al., 2013).

In summary, this study suggests that $H$. rubra $\times H$. laevigata hybrids maintain their $\dot{\mathrm{M}}_{\mathrm{O}_{2}}$, heart rate, and movement over a broader environmental range compared with their parental pure species. Maintaining optimal physiological rates during environmental fluctuations may contribute to the hybrid growth advantage in the environmentally unstable aquaculture environment. Thus, future plans by aquaculture farmers to increase oxygen levels in grow-out tanks on their farms may be more beneficial for pure species than for hybrids. This suggestion, however, should be considered with care and long-term investigations of growth rates and energetics of pure and hybrid abalone at varying and stable environmental conditions should be conducted to further improve the understanding of the apparent growth advantage in hybrids. While the present study provides some evidence for hybrid vigor in farmed abalone, it remains unclear why the prevalence of hybrids is low in nature.

\section{Conflict of interest}

The authors declare that the research was conducted in the absence of any commercial or financial relationships that could be construed as a potential conflict of interest.

\section{Author contribution}

KA, SJA, AJM, TDC, and NGE developed the experimental design, KA conducted the experiments. $\mathrm{KA}, \mathrm{ADH}$, and RL analyzed the data. KA wrote the manuscript and received constructive comments and revisions from all co-authors. All authors have approved the final version to be published.

\section{Acknowledgements}

We thank Jade Tiger Abalone for providing their abalone for this study. KA is grateful for support from the University of Tasmania, the Sense-T Program and CSIRO.

\section{References}

Abramoff, M.D., Magalhaes, P.J., Ram, S.J., 2004. Image processing with ImageJ. Biophoton. Int. 11, 36-42.

Beiras, R., Camacho, A.P., Albentosa, M., 1995. Short-term and long-term alterations in the energy budget of young oyster Ostrea edulis L. in response to temperature change. J. Exp. Mar. Biol. Ecol. 186, 221-236.

Brown, L.D., 1995. Genetic evidence for hybridization between Haliotis rubra and H. laevigata. Mar. Biol. 123, 89-93.

Brown, L.D., Murray, N.D., 1992. Genetics relationships within genus Haliotis. In: Shepherd, S., Tegner, M., Guzman del Proo, S. (Eds.), Abalone of the World: Biology, Fisheries and Culture. Blackwell Scientific Publications, London, pp. 19-23.

Cenni, F., Parisi, G., Gherardi, F., 2009. Use of space and costs/benefits of locomotion strategies in the abalone, Haliotis tuberculata. Ethol. Ecol. Evol. 21, 15-26.

Chen, N., Luo, X., Gu, Y., Han, G., Dong, Y., You, W., Ke, C., 2016. Assessment of the thermal tolerance of abalone based on cardiac performance in Haliotis discus hannai, $\mathrm{H}$. gigantea and their interspecific hybrid. Aquaculture 465, 258-264.

Collins, C., 2013. Young abalone in the fast lane: a protein boost for young abalone sets the stage for a more profitable industry. FRDC News 21, 30-33.

Cowles, R.B., Bogert, C.M., 1944. A preliminary study of the thermal requirements of desert reptiles. Iguana 83, 53. 
Currie, K.L., Davidson, H., Bansemer, M.S., Harris, J.O., Stone, D.A., 2016. Ventral videographic assessment of the feeding behavior of juvenile greenlip [Haliotis laevigata (Donovan, 1808)] and hybrid (H. laevigata $\times$ Haliotis rubra) abalone in response to dietary and temperature manipulation. J. Shellfish Res. 35, 641-651.

Dahlhoff, E., Somero, G.N., 1993. Effects of temperature on mitochondria from abalone (Genus Haliotis) - adaptive plasticity and its limits. J. Exp. Biol. 185, 151-168.

Denny, M., 1980. Locomotion: the cost of gastropod crawling. Science 208, 1288-1290.

Donovan, D., Carefoot, T., 1997. Locomotion in the abalone Haliotis kamtschatkana: pedal morphology and cost of transport. J. Exp. Biol. 200, 1145-1153.

Fordham, D.A., Mellin, C., Russell, B.D., Akçakaya, R.H., Bradshaw, C.J., Aiello-Lammens, M.E., Caley, J.M., Connell, S.D., Mayfield, S., Shepherd, S.A., Brook, B.W., 2013. Population dynamics can be more important than physiological limits for determining range shifts under climate change. Glob. Chang. Biol. 19, 3224-3237.

Gabriel, W., Lynch, M., 1992. The selective advantage of reaction norms for environmental tolerance. J. Evol. Biol. 5, 41-59.

Gilroy, A., Edwards, S.J., 1998. Optimum temperature for growth of Australian abalone: preferred temperature and critical thermal maximum for blacklip abalone, Haliotis rubra (Leach), and greenlip abalone, Haliotis laevigata (Leach). Aquac. Res. 29, 481-485.

Grieshaber, M.K., Hardewig, I., Kreutzer, U., Pörtner, H.O., 1993. Physiological and metabolic responses to hypoxia in invertebrates. In: Reviews of Physiology, Biochemistry and Pharmacology. 125. Springer, Berlin Heidelberg, pp. 43-147.

Guo, X.M., 2009. Use and exchange of genetic resources in molluscan aquaculture. Rev. Aquac. 1, 251-259.

Hamilton, M., Kube, P., Elliott, N., McPherson, L., Krsinich, A., 2009. Development of a breeding strategy for hybrid abalone. In: Proceedings of the Association of Advancements in Animal Breeding and Genetics. 18, pp. 350-353.

Harris, J.O., Maguire, G.B., Edwards, S.J., Johns, D.R., 1999. Low dissolved oxygen reduces growth rate and oxygen consumption rate of juvenile greenlip abalone, Haliotis laevigata Donovan. Aquaculture 174, 265-278.

Hawkins, A.J., 1995. Effects of temperature change on ectotherm metabolism and evolution: metabolic and physiological interrelations underlying the superiority of multi-locus heterozygotes in heterogeneous environments. J. Therm. Biol. 20, 23-33.

Hawkins, A.J., Day, A.J., 1999. Metabolic interrelations underlying the physiological and evolutionary advantages of genetic diversity. Am. Zool. 39, 401-411.

Hellicar, A.D., Rahman, A., Smith, D.V., Smith, G., McCulloch, J., Andrewartha, S, Morash, A., 2015. An algorithm for the automatic analysis of signals from an oyster heart rate sensor. IEEE Sensors J. 15, 4480-4487.

Lenth, R.V., 2016. Least-squares means: the R package lsmeans. J. Stat. Softw. 69, 1-33.

Li, X., 2008. Abalone Aquaculture Subprogram: Selective Breeding of Farmed Abalone to Enhance Growth Rates (II). SARDI Aquatic Sciences, South Australian Research and Development Institute.

Liang, S., Luo, X, You, W., Luo, L, Ke, C, 2014. The role of hybridization in improving the immune response and thermal tolerance of abalone. Fish and Shellfish Immunology 39, 69-77.

Marshall, D.J., McQuaid, C.D., 1992. Relationship between heart rate and oxygen consumption in the intertidal limpets Patella granularis and Siphonaria oculus. Comparative Biochemistry and Physiology A 103, 297-300.
Morash, A.J., Alter, K., 2015. Effects of environmental and farm stress on abalone physiology: perspectives for abalone aquaculture in the face of global climate change. Rev. Aquac. 7, 1-27.

Muggeo, V.M.R., 2008. Segmented: an R package to fit regression models with broken-line relationships. R News 8, 20-25.

Myrick, C.A., 2009. A low-cost system for capturing and analyzing the motion of aquatic organisms. J. N. Am. Benthol. Soc. 28, 101-109.

Newell, R.C., Kofoed, L.H., 1977. Adjustment of the components of energy balance in the gastropod Crepidula fornicata in response to thermal acclimation. Mar. Biol. 44, 275-286.

Pinheiro, J., Bates, D., DebRoy, S., Sarkar, D., Core Team, R., 2016. nlme: Linear and Nonlinear Mixed Effects Models. R Package. 3, 1-128.

R Core Team, 2016. R: A Language and Environment for Statistical Computing. R Foundation or Statistical Computing, Vienna, Austria. URL https://www.R-project.org.

Ragg, N.L.C., Taylor, H.H., 2006. Heterogeneous perfusion of the paired gills of the abalone Haliotis iris Martyn 1784: an unusual mechanism for respiratory control. J. Exp. Biol. 209, 475-483.

Robinson, N., Smith, B., Cooke, I., Strugnell, J., 2013. A snail's pace: a preliminary analysis of the effects of stress and genetics on movement of Haliotis. Aquaculture 376-379, 25-35.

Schindelin, J., Rueden, C.T., Hiner, M.C., Eliceiri, K.W., 2015. The ImageJ ecosystem: an open platform for biomedical image analysis. Mol. Reprod. Dev. 82, 518-529.

Searle, T., Roberts, R.D., Lokman, P.M., 2006. Effects of temperature on growth of juvenile blackfoot abalone, Haliotis iris Gmelin. Aquac. Res. 37, 1441-1449.

Seebacher, F., Brand, M.D., Else, P.L., Guderley, H., Hulbert, A.J., Moyes, C.D., 2010. Plasticity of oxidative metabolism in variable climates: molecular mechanisms. Physiol. Biochem. Zool. 83, 721-732.

Shepherd, S., 1973. Studies on Southern Australian abalone (genus Haliotis). I. Ecology of five sympatric species. Mar. Freshw. Res. 24, 217-258.

Sokolova, I.M., Pörtner, H.O., 2003. Metabolic plasticity and critical temperatures for aerobic scope in a eurythermal marine invertebrate (Littorina saxatilis, Gastropoda: Littorinidae) from different latitudes. J. Exp. Biol. 206, 195-207.

Sokolova, I.M., Frederich, M., Bagwe, R., Lannig, G., Sukhotin, A.A., 2012. Energy homeostasis as an integrative tool for assessing limits of environmental stress tolerance in aquatic invertebrates. Mar. Environ. Res. 79, 1-15.

Somero, G.N., 2002. Thermal physiology and vertical zonation of intertidal animals: optima, limits, and costs of living. Integr. Comp. Biol. 42, 780-789.

Steinarsson, A., Imsland, A.K., 2003. Size dependent variation in optimum growth temperature of red abalone (Haliotis rufescens). Aquaculture 224, 353-362.

Storey, K.B., Storey, J.M., 1990. Metabolic rate depression and biochemical adaptation in anaerobiosis, hibernation and estivation. Q. Rev. Biol. 65, 145-174.

Toro, J.E., Vergara, A.M., Gallegillos, R., 1996. Multiple-locus heterozygosity, physiology and growth at two different stages in the life cycle of the Chilean oyster Ostrea chilensis. Mar. Ecol. Prog. Ser. 134, 151-158.

Werner, I., Flothmann, S., Burnell, G., 1995. Behaviour studies on the mobility of two species of abalone (Haliotis tuberculata and $\mathrm{H}$. discus hannai) on sand: implications for reseeding programmes. Mar. Freshw. Res. 46, 681-688. 